\title{
Technical Note: A comparison of methods to determine plant successional stages
}

\author{
SUSAN R. WINSLOW AND BOK F. SOWELL
}

Authors are agronomist, USDA/NRCS, Plant Materials Center, Bridger, Mont. 59014; and assistant professor, Department of Animal and Range Sciences, Montana State University, Bozeman, Mont. 59717.

Abstract

Twenty-six, 0.04 ha macroplots were sampled on 9 range sites in southwestern Montana to compare successional scores and condition classifications of range condition analysis and United States Forest Service (USFS) Ecodata and Ecopac (Strata) analysis methods. Range condition scores $(0-100 \%)$ and range condition classes (poor, fair, good, excellent) were derived from the traditional Soil Conservation Service range condition analysis method, with the exception that only major decreaser and increaser graminoids and shrubs were individually clipped and bagged. Ecological status scores (1-100\%) and ecological condition classes (low, mid, high, very high) were determined with United States Forest Service Ecodata methods. Range condition score means were greater $(p<0.02)$ than ecological status score means $(48 \%$ vs $41 \%)$. Standing crop biomass affected differences ( $p<0.001)$ between range condition scores and ecological status scores. Lower producing sites had greater range condition scores than ecological status scores and higher producing sites had greater ecological status scores than range condition scores. Range condition classes and ecological condition classes were not independent $(\mathrm{p}<0.02$ ). Differences between the 2 methods were attributable to the use of species composition by weight for the range condition analysis and the use of percent canopy cover by Ecodata methods. Rangeland managers trying to determine successional status should realize that range condition analysis and Ecodata methods produce similar condition classes but different condition scores.

Key Words: Range condition, seral stages, plant communities, succession

Range condition analysis was developed to monitor forage productivity and to evaluate grazing effects on plant communities. Methods developed by the Soil Conservation Service (SCS) have been the standard to determine range condition and trends in the western United States for many years (Svejcar and Brown 1991). Changes in land management policy began in the 1960s after societal awareness identified a need for increased conservation and improvement of the environment leading to the adoption of ecological guidelines for ecosystem management by the U.S. Forest Service (USFS) (Robertson 1992).

The authors wish to express thanks to the USFS for their cooperation and assistance in the completion of this project. Thanks to the Flying D Ranch for access.

Manuscript Accepted 30 May 1999.

\section{Resumen}

Se muestrearon 26 macroparcelas (0.04 ha) en 9 sitios de pastizal del Sudoeste de Montana para comparar las calificaciones sucesionales y las clasificaciones de condición del análisis de condición del pastizal y de los métodos de análisis Ecodata y Ecopac ("Strata") del Servicio Forestal de los Estados Unidos (USFS).Las calificaciones de condición del pastizal (0-100\%) y las clases de condición del pastizal (pobre, regular, bueno y excelente) se derivaron del método tradicional de análisis de condición del pastizal del Servicio de Conservación de Suelos, con la excepción de que solo las principales especies de gramíneas y arbustos decresores e incresores se cortaron y empaquetaron individualmente. Las calificaciones del estado ecológico (1$100 \%$ ) y las clases de condición ecológica (bajo, medio, alto y muy alto) se determinaron con los métodos Ecodata del Servicio Forestal de los Estados Unidos. Las medias de las calificaciones de la condición del pastizal fueron mayores $(p<0.02)$ que las medias de la calificación del estado ecológico (48\% vs $41 \%)$. La biomasa de la cosecha en pie afecto las diferencias $(\mathbf{p}<0.001)$ entre las calificaciones de la condición del pastizal y las calificaciones del estado ecológico. En los sitos de baja producción las calificaciones de condición de pastizal fueron mayores que las del estado ecológico, en sitos con alta producción las calificaciones del estado ecológico fueron mayores que las de la condición del pastizal. Las clases de condición del pastizal y las de condición ecológica no fueron independientes $(\mathbf{p}<0.02)$. Las diferencias entre los 2 métodos se atribuyeron al uso de la composición de especies por peso para el caso de la condición de pastizal y al uso del porcentaje de cobertura de copa en los métodos Ecodata. Los manejadores el pastizal que intentan determinar el estado sucesional deberán reconocer que el análisis de condición del pastizal y los métodos Ecodata producen clases de condición similares pero diferentes calificaciones de condición.

Traditional methods employed by SCS to determine range condition scores and range condition classes were based on plant species composition by dry weight. These values were compared to "climax" for a given range site. Range condition scores $(0-100 \%)$ were determined according to the similarity of current vegetation compared to climax vegetation. Vegetation was further categorized into poor $(0-25 \%)$, fair (26-50\%), good $(51-75 \%)$ and excellent (76-100\%) condition classes to correspond with low, mid, high and very high seral stages. This method presents problems because climax vegetation is difficult to determine and secondary plant successional patterns may vary greatly on similar sites. Limitations of these methods have 
prompted federal agencies to develop other seral stage assessment methods which are more ecologically based.

There appears to be a trend by agencies towards more qualitative or observational methods to assess "range health" or "proper functioning condition". These methods do not yield any quantitative data for determining changes in plant communities over time. Therefore, some agencies have attempted to use quantitative methods to assess seral stages, which are based on different critera for determining potential natural plant communities.

In 1987, the Northern Region of the USFS began development of Ecodata and Ecopac as a standardized approach for environmental analysis and plant community classification (USDA 1987). The Northern Region proposed to inventory and classify vegetation based on Ecodata sampling methods and manage 3 million ha of public grazing allotments based on a determination of ecological status (RISC 1983).

The Strata program categorizes current vegetation and compares it to potential natural communities based on canopy cover. The degree of similarity between current vegetation and potential natural community is determined by Sorensen's quotient of similarity (Sorensen 1948). This quotient is determined by plant species occupancy in sampled communities compared to reference plant communities. An ecological status score is given from 1 to 100 and the seral stage is classified into 1 of 4 ecological condition classes (low, mid, high, very high) in $25 \%$ increments (USDA 1987).

The relationship of Ecodata sampling methods to standard range condition analysis methods has not been established and a lack of continuity exists in information gathered with different methods. A comparison of the Ecodata method to the standard range condition analysis would provide managers a basis for understanding Ecodata's relationship between ecolog ical condition classes and range condition classes. The purpose of this study was to compare successional scores and condition classes derived from range condition analysis and Ecodata sampling methods on a variety of range sites. The objectives were to: 1) compare range condition scores and ecological status scores; 2) compare range condition classes and ecological condition classes; and 3) to determine those environmental parameters that may influence the differences between the range condition and ecological status scores. To our knowledge, similar pub- lished comparisons between these methods do not exist.

\section{Methods}

\section{Study Area}

The study was conducted on the Flying D Ranch, $\left(45^{\circ} \mathrm{N}, 111^{\circ} \mathrm{W}\right), 16 \mathrm{~km}$ southwest of Bozeman, Mont., in Gallatin and Madison counties (USDA 1989). The 60,700 hectare ranch is characterized by intermontane valleys at 1,280-2,300 m elevations. The majority of the ranch receives $38-48 \mathrm{~cm}$ of annual precipitation an average annual temperature of $4.4^{\circ} \mathrm{C}$ and a 75 day frost-free period (USDA 1989).

Soils were classified as Argie, Pachie, Calcic or Lithic Cryoborolls (USDA 1989). Bridger, Earcree, Hanson, OrofinoPoin, and Poin-Sebud soil series with sandy, silty, and clay loam textures dominated the study area and were frequently modified by gravel, cobble, or stone fragments (USDA 1989, 1994). Potential natural communities varied with range site and average forage production values ranged from 300 to $1,200 \mathrm{~kg} / \mathrm{ha}^{-1}$ (USDA 1989). Dominant plant species across range sites included big sagebrush (Artemesia tridentata [Nutt.]), bluebunch wheatgrass (Pseudoroegneria spicata [Pursh] A. Love), Idaho fescue (Festuca idahoensis [Elmer]), lupine (Lupinus L), needle-and-thread (Stipa comata [Trin. and Rupr.]), prairie Junegrass (Koeleria macrantha [Ledeb.] J.A. Schultes), western needlegrass (Stipa occidentalis) Thurb. ex S. Wats.), and western wheatgrass (Pascopyrum smithii [Rydb.] A. Love) (Ross and Hunter 1976).

\section{Site Descriptions and Locations}

Twenty-six, $11.3 \mathrm{~m}$ radius (0.04 ha) permanent Ecodata macroplots were established on the ranch as part of a baseline range condition inventory in 1990. Sampling was concentrated in grassland and shrub steppe rangeland to evaluate a variety of range sites (Westech 1991). Ecodata macroplots were established in major range sites and location was based on vegetation composition, soils, and precipitation information. Site selection in riparian corridors was minimal due to significant modification of lowland vegetation by livestock grazing and apparent poor condition. Upland areas were sampled more intensively to determine the extent of fair to excellent condition range sites and a number of range sites were sampled at several locations. Range condi- tion and ecological status were compared on range sites/habitat types that had species composition data available for similarity analysis. Macroplots were established in a representative, homogenous range site/habitat type and permanently located with a $1.6-\mathrm{cm}$ diameter capped rebar pin. Exact site locations and landmark descriptions are reported in Westech (1991).

\section{Sampling}

Plots were sampled in August 1990 according to the Ecodata ocular method, using the Ecodata ocular method, as outlined in Chapter 4 of the Ecosystem Classification Handbook (USDA 1987). Environmental features of the macroplot were noted and potential natural community and habitat type were determined with classification systems developed by Hansen et al. (1988), Mueggler and Stewart (1980), and Pfister et al. (1977). Range site was determined using SCS soil survey maps (USDA 1989). Site characteristics described included: soil type, plot position on the landscape, parent material, aspect, elevation, percent slope, and ground cover characteristics. Vegetation structure and production for the macroplot were recorded. Identification of dominant species (height $\mathrm{x}$ canopy cover) by vertical layer and estimation of total percent vegetative cover by life-form were determined.

Annual standing crop biomass was determined by clipping vegetation. Plant species identified as major decreaser graminoids, major increaser graminoids, or shrubs were individually clipped and bagged (USDA 1981). Other perennial forb species, annual/biennial forbs, minor decreaser graminoids, minor increaser graminoids, or annual graminoids were grouped into 1 separate class. Actual production was determined from 3 randomly placed, $0.5 \times 1.0 \mathrm{~m}$ microplots within an Ecodata macroplot. Current year aboveground herbaceous biomass for each class of vegetation was clipped to ground level and bagged. Production samples were ovendried at $70^{\circ} \mathrm{C}$ until constant weight was achieved (48-96 hours). Biomass ( $\left.\mathrm{kg} \mathrm{ha}^{-1}\right)$ for each vegetation class, from each microplot, were used in determining mean macroplot production.

Ocular Plant Species Data Form 4 (USDA 1987) was used to record characteristics of the macroplot vegetation. Species life-form, percent canopy cover class, and mean height to the nearest foot were defined. Plants were identified by genus and species using Dorn (1984), Great Plains Flora Association (1986), 
Hitchcock et al. (1955-1969), and Hitchcock and Cronquist (1973). The USFS species list (USDA 1987) was used as standard nomenclature for entry into the plant composition database.

\section{Determination of Range Condition and Classification}

Range condition calculations were based on clipped forage weights of each vegetation class. Relative percent composition, for each vegetation class in each plot, was determined by dividing the dry weight of the class by total plot production. Existing relative percent compositions were then compared to the climax community species percent composition listed in the USDA SCS range site technical guides (1977). Actual amounts, not in excess of that shown in the guide, were totaled for all vegetation classes to arrive at the numerical range condition scores, a relative ecological rating of floristic similarity to climax community, for the plot (USDA 1981). The plot was then classified into 1 of 4 range condition classes determined by $25 \%$ increments of the range condition scores (USDA 1976).

\section{Determination of Ecological Status and Condition}

Data from each of the 26 macroplots was entered into the Ecodata general form and plant composition data bases (Data General System 1985). The data bases were linked to the Ecodata analysis package (Ecopac) through the Utility system and checked for errors (USDA 1987). The Plotid program was used to group the Ecodata macroplots and create text files for input into the plant community analysis program, Strata. A species synthesis table (species abundance by plot and strata) and constancy-average table (species canopy cover) was generated to select plants common to the 26 macroplots and the 159 plots sampled by Mueggler and Stewart (1980). Plant species composition of Mueggler and Stewart (1980) plots was based on forty, $0.2 \times 0.5 \mathrm{~m}$ microplots per $20 \times 20 \mathrm{~m}$ (0.04 ha) macroplot. The number of species common to both plots was limited to 88 to reduce noise in the similarity analysis (Gauch 1982). The Mueggler and Stewart (1980) plots were grouped into potential natural communities. The Ecopac subroutine, Strata, characterized differences, based solely on the estimated species percent canopy cover, between the existing 26 macroplots and the potential natural communities (habitat type strata) of Mueggler and Stewart
(1980). The species composition of each study macroplot was compared to all 5 habitat types (potential natural communities) by plot-to-strata similarity analysis. The potential natural communities were Pseudoroegneria spicata/Poa sandbergii (Psespi/Poasan), Artemisia tridentata/Festuca idahoensis (Arttri/Fesida), Festuca idahoensis/Elymus caninus/Geranium viscosissimum phase (Fesida/ElyCan/Gervis), Festuca idahoensis/Pascopyrum smithii (Fesida/Passmi), and Festuca idahoensis/Pseudoroegneria spi cata (Fesida/Psespi). The numerical macroplot ecological status score was calculated as degrees of floristic similarity to potential natural communities using Sorensen's (1948) coefficient $K=100$ $(2 \mathrm{c} / \mathrm{a}+\mathrm{b})$, where $\mathrm{c}$ is the sum of percent canopy cover of a single species in two opposing plots, a is the canopy cover of all species in a plot (ie macroplot), and b is the canopy cover of all species in the other plot (ie Mueggler and Stewart's potential natural community plot). The plot was then classified into 1 of 4 ecological condition classes as determined by $25 \%$ increments of the ecological status scores (USDA 1992).

\section{Statistical Procedures}

Differences between the mean range condition scores and ecological status scores were compared using a non-parametric, two-tailed Wilcoxon's signed rank test (Steel and Torrie 1980). This was considered to be a more conservative approach than either the paired t-test or analysis of variance since the two sampling methods were employed at the same location, on the same day. The Wilcoxon's signed rank test only assumes data can be ranked and there are very few ties when ranking values. No other assumptions of independent sampling or normally distributed differences are necessary. There was only one tied rank in the data, therefore this was considered a valid statistical test. Plot was considered the experimental unit for this and all subsequent analyses. A paired t-test (SAS 1988) was used to compare differences of range condition scores and ecological status scores within similar range sites grouped across precipitation zones.

Range condition classes were poor, fair, good, and excellent and ecological condition classes were low, moderate, high, and very high. The 4 condition classes, for both methods, represented successional score percentage breaks of 0-25, 26-50, 51-75, and 76-100. Analyses of range condition classes and ecological condition classes were based on 21 of the 26 plots. A $2 \times 2$ contingency table was used to meet the criteria of having a minimum expected cell count of 5 (McClave and Dietrich 1985). Five plots were excluded because they represented single occurrences in the columns of the contingency table which render the statistical inference invalid for those columns. Class scores were transformed into numerical form (1-4). To determine the degree of independence between range condition classes and ecological condition classes, ChiSquare analysis (MSUStat 1994) was conducted with the 2-way contingency table. Association groups were determined according to the probability of such associations occurring by chance.

The difference between range condition scores and ecological status scores for each of the 26 plots was determined. Regression analysis (SAS 1988) was used to determine the influences of aspect, elevation, precipitation, production, range site, and slope on differences between range condition scores and ecological status scores. Range sites were grouped irrespective of precipitation zone. All statistical comparisons were evaluated at $p<0.05$.

\section{Results}

Five hundred fifty-two vascular plant taxa were identified in the survey of the 9 range sites. Forage production values ranged from $139 \mathrm{~kg} \mathrm{ha}^{-1}$ on the very shallow $38-48 \mathrm{~cm}$ precipitation range site, to $4,708 \mathrm{~kg} \mathrm{ha}^{-1}$ on the silty $50+\mathrm{cm}$ precipitation range site (Westech 1991). Range condition scores varied from $15 \%$ on a silty $50+\mathrm{cm}$ precipitation range site to $78 \%$ on the silty $25-26 \mathrm{~cm}$ precipitation range site. Poor range condition classes occurred on $4 \%$ of the plots, fair condition on $54 \%$ of the plots, $35 \%$ of the plots were found to be in good condition, and $8 \%$ were in excellent condition. Ecological status scores varied from $13 \%$ on the Fesida/Passmi habitat type to $57 \%$ on the Psespi/Poasan/Sticom habitat type. Low ecological condition classes occurred on $12 \%$ of the plots, $62 \%$ of the plots were moderate, and $27 \%$ were classified as high ecological condition.

There was a $15 \%$ difference $(\mathrm{p}<0.02)$ between the range condition scores mean $(48 \%)$ and the mean ecological status scores $(41.3 \%)$. There were no differences $(p>0.05)$ between range condition scores and ecological status scores within range sites (Table 1) with 1 exception. This occurred on the very shallow sites $(n=2)$, 
Table 1. Comparison of mean range condition scores (RCS) and ecological status scores (ESS) for 24 macroplots in the same range sites (grouped across precipitation zones) in southwest Montana.

\begin{tabular}{lrccc}
\hline \hline Range Site & $\mathrm{n}$ & $\mathrm{RCS}$ & $\mathrm{ESS}$ & P-Value \\
\hline & & $(\%)$ & $(\%)$ & \\
Silty & 13 & 49 & 37 & 0.54 \\
Shallow & 7 & 47 & 44 & 0.78 \\
Very Shallow & 2 & 57 & 27 & 0.02 \\
Overflow & 2 & 24 & 27 & 0.82 \\
\hline
\end{tabular}

where productivity was lower than other range sites.

Categorizing vegetation into mid or fair ecological condition and high or good range condition classes resulted in 16 of 21 plots being placed in the same seral categories. Chi-Square analyses revealed that range condition and ecological condition methods used to categorize condition classes or seral stages were not independent $(\mathrm{p}<0.02)$.

Regression analysis indicated that aspect, elevation, habitat type, and precipitation did not affect differences between range condition scores and ecological status scores (Table 2). Production (Fig. 1) and range site $(\mathrm{p}<0.001$ and $\mathrm{p}<0.04)$ were the only variables that affected the differences between range condition scores and ecological status scores. The equations of linear relationship between ecological status scores minus range condition scores and all other variables are provided in Table 2. Lower producing sites had greater range condition scores than ecological status scores and higher producing sites had greater ecological status scores than range condition scores (Fig. 1).

\section{Discussion}

Differences between range condition scores and ecological status scores were probably related to different assessment methods. Relative percent species compo-
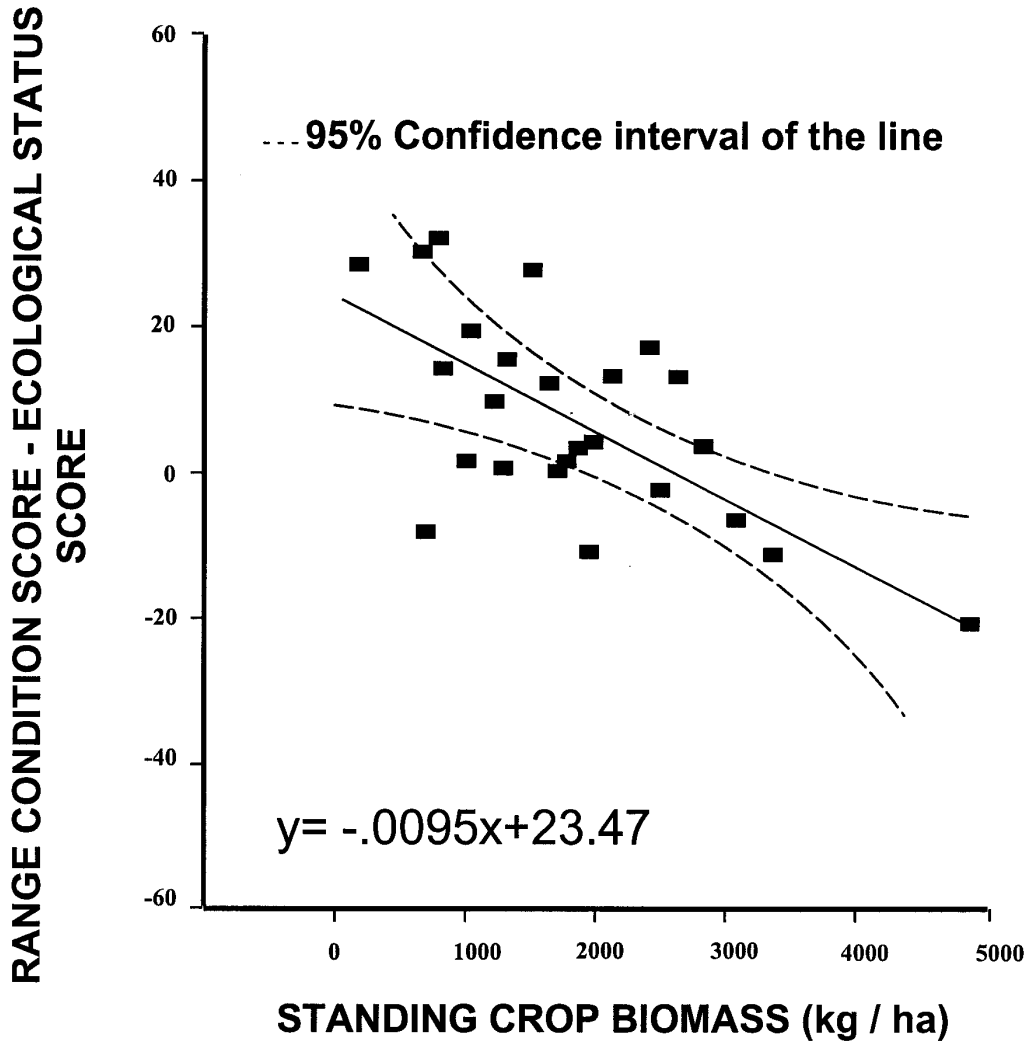

Fig. 1. Standing crop biomass effects on range condition score minus ecological status score on 26 macroplots in southwest Montana.

sition by weight used in the range condition analysis method favors plants that produce more biomass, while the Ecodata system emphasizes canopy cover. Payne (1974) found that the average correlation of cover and weight was 0.62 for all grass species and provided evidence that correlations between weight and cover could vary from $R=0.98$ to $R=0.14$ depending on the individual plant species. Therefore, differences between ecological status scores and range condition scores could be due to variable correlations between plant weight and canopy cover.

Percent canopy cover estimates used with the Ecodata method are placed in cover class ranges, assigned a standard

Table 2. Simple linear equations and statistics for the effect of seven variables on the differences between range condition score and ecological status score in southwestern Montana.

\begin{tabular}{llll}
\hline \hline Source & \multicolumn{1}{c}{ Equation } & $\mathrm{R}$ & P-Value \\
\hline Aspect & $\mathrm{y}=-0.03 \mathrm{x}+13.02$ & 0.24 & 0.21 \\
Elevation & $\mathrm{y}=-0.003 \mathrm{x}+12.87$ & 0.1 & 0.83 \\
Range Sites & $\mathrm{y}=5.01 \mathrm{x}+-2.28$ & 0.4 & 0.04 \\
Habitat Type & $\mathrm{y}=-0.24 \mathrm{x}+8.09$ & 0.1 & 0.78 \\
Precipitation & $\mathrm{y}=-0.61 \mathrm{x}+33.49$ & 0.17 & 0.38 \\
Standing Crop Biomass & $\mathrm{y}=-0.0095 \mathrm{x}+23.47$ & 0.32 & 0.001 \\
Slope & $\mathrm{y}=0.31 \mathrm{x}+0.39$ & 0.67 & 0.11 \\
\hline
\end{tabular}

class midpoint, and assigned a class code. For example, in the canopy cover range of $1-<5 \%$, the midpoint is $3.0 \%$, and in the range of $35-45 \%$, the midpoint is $40.0 \%$ (the median). The assigned midpoint may be biased by extremely low or high estimates (Daubenmire 1968). The experience of the investigator may affect the estimate. Plots with very low foliage cover are likely to be underestimated, and plots with greater foliar cover are likely to be overestimated (Meuller-Dombois and Ellenberg 1974). This may partially explain why ecological status scores are lower on sites with lower production and higher on sites with greater production.

Differences in the scores were probably not attributed to different concepts of climax or potential natural communities classification. Range site and habitat type have been found to classify the land unit and potential vegetation in essentially the same fashion (Hironaka 1989). Both the range site and habitat type concepts are based on soil characteristics unique to a site and on the differences in expected climax plant composition and production on the same site.

Mueggler and Stewart (1980) sampled 0.04 ha macroplots near-pristine areas and 
areas subject to mild grazing disturbance to determine climax plant communities. Our study used the same size macroplots as Mueggler and Stewart (1980), therefore it is unlikely that differences between the 2 methods were the result of plot size influences.

Range managers often rely on condition classes for management purposes. There were no differences in range condition classes and ecological condition classes. It appears that these classifications could be used interchangeably.

\section{Conclusions}

In this study, the mean of the ecological status scores, as determined by USFS Ecodata, was lower $(p<0.02)$ than the mean of the range condition scores, as determined by the SCS range condition analysis method. When conducting range inventories, Ecodata methods may indicate a decline in vegetation resources when the results are compared to range condition analysis methods. Differences between ecological status scores and range condition scores were probably due to variable correlations between plant weight and cover. Resulting condition classification from both Ecodata and range condition analysis methods were the same. These findings indicate that categorization of vegetative seral stages are comparable and that both methods are based on similar comparisons to climax or potential natural plant communities.

\section{Literature Cited}

Data General System. 1985. AOS/VS INFOS II system user's guide. Data General Corp., Westburo, Mass.

Daubenmire, R. 1968. Plant communities, a textbook of plant synecology. Harper \& Row, New York, N.Y.

Dorn, R.D. 1984. Vascular plants of Montana. Mountain West Publishing, Cheyenne, Wyo.

Gauch, H.G. Jr. 1982. Multivariate analysis in community ecology. Cambridge Univ. Press, Cambridge, Mass.

Great Plains Flora Association. 1986. Flora of the Great Plains. University Press of Kansas, Lawrence, Kan.

Hansen, P.L., S.W. Chadde, and R.D. Pfister. 1988. Dominance types of Montana. Montana Riparian Association. Misc. Publ. Number 49, School of Forestry, Univ. of Montana, Missoula, Mont.

Hironaka, M. 1989. Relationship of habitat type and range site, p. 300-301. In: D.E. Ferguson, P. Morgan, and F.S. Johnston (compilers), Proc. Land Classifications
Based on Vegetation: Applications for Resource Management. Moscow, Idaho. USDA U.S. Forest Serv. Gen. Tech. Rep. INT-257. Ogden, Ut.

Hitchcock, C.L. and A. Cronquist. 1973. Flora of the Pacific Northwest. Univ. of Washington Press, Seattle, Wash.

Hitchcock, C.L., A. Cronquist, M. Ownbey, J.W. Thompson. 1955-1969. Vascular plants of the Pacific Northwest. Vols. 1-5, Univ. of Washington Press, Seattle, Wash.

McClave, J.T. and F.H. Dietrich. 1985. Statistics. Dellen Publishing Company c/o Macmillan Publishing Company Front and Brown Streets, Riverside, N. J. 08075.

MSUStat. 1994. MSUStat Statistical Analysis Package, Users Guide. Res. \& Dev. Inst., Inc. Bozeman, Mont.

Mueggler, W.F., and W.L. Stewart. 1980. Grassland and shrubland habitat types of Western Montana. USDA U.S. Forest Serv. Gen. Tech. Rep. INT-66. Ogden, Utah.

Mueller-Dombois, D., and H. Ellenberg. 1974. Aims and methods of vegetation ecology. John Wiley \& Sons, New York, N.Y.

Payne, G.F. 1974. Cover-weight relationships. J. Range Manage. 27:403-404.

Pfister, R.D., B.L. Kovalchik, S.F. Arno, and R.C. Presby. 1977. Forest habitat types of Montana. USDA U.S. Forest Ser. Gen. Tech. Rep. INT-34. Ogden, Ut.

RISC. 1983. Guidelines and Terminology of Range Inventories and Monitoring. Rep. of Range Inventory Standardization Com. Soc. for Range Manage., Denver, Colo. pp. 13.

Robertson, F.D. 1992. Ecosystem management of the national forests and grasslands. USDA USFS, Wash., D.C. 1330-1 policy letter, 4 June 1992.

Ross, R.L., and H.E. Hunter. 1976. Climax vegetation of Montana. USDA Soil Conservation Service, Bozeman, Mont. 64 p.

SAS Institute Inc. 1988. SAS/Stat users guide, version 6. SAS Institute Inc., Cary, N.C.

Sorensen, T. 1948. A method of establishing groups of equal amplitude in plant sociology based on similarity of species content. Det Kong. Danske Vidensk.Selsk. Biol. Skr. 5(4):1-34. Copenhagen.

Steel, R.G.D. and J.H. Torrie. 1980. Principles and procedures of statistics, a biometrical approach. McGraw-Hill Book Company, New York, N.Y.

Svejcar, T., and J.R. Brown. 1991. Failures in the assumptions of the condition and trend concept for management of natural ecosystems. Rangelands 13:165-167.

USDA Natural Resources and Conservation Service. 1994. Soil survey of Gallatin County area, Mont. Bozeman, Mont.

USDA Soil Conservation Service. 1976. National range handbook. NRH-1. Wash., D.C.

USDA Soil Conservation Service. 1977. Grazing guide for potential climax forest sites and condition classes, Montana foothills and mountains area. Bozeman, Mont.

USDA Soil Conservation Service. 1981. Technical guide to range sites and condition classes, Montana foothills and mountains.
National soils handbook, amend. MT-1. p. 407(1)-407(6). Bozeman, Mont.

USDA Soil Conservation Service. 1989. Soil survey of Madison County area, Mont. Bozeman, Mont. 384p. plus maps.

USDA U.S. Forest Service. 1987. Ecosystem classification handbook. Chapter fourEcodata sampling method. FSH 12/87 R-1. Missoula, Mont.

USDA U.S. Forest Service. 1992. Draft ecosystem classification and analysis guide. Chapter five-Plot level analysis programs. FSH 7/92 R-1. Missoula, Mont.

Westech. 1991. Baseline range condition evaluation and inventory of sensitive plant species for the Flying D Ranch, Madison and Gallatin Counties, Montana, 1990. Western Technology and Engineering, Inc. Helena, Mont. 